\title{
Adiwiyata Program Implementation in Inculcating Environmental Care Characters: A Literature Review
}

\author{
Prima Fauzani ${ }^{1, *}$ Tien Aminatun ${ }^{2}$ \\ ${ }^{1}$ Master of Biology Education, Faculty of Mathematics and Natural Sciences, Universitas Negeri Yogyakarta, \\ Indonesia \\ ${ }^{2}$ Department of Biology Education, Faculty of Mathematics and Natural Sciences, Universitas Negeri \\ Yogyakarta, Indonesia \\ *Corresponding author. Email: prima1440pasca.2019@student.uny.ac.id
}

\begin{abstract}
Adiwiyata is a program implemented to create a school that cares, has an insight, and has an environmental culture. There are four main components in the implementation of the Adiwiyata program, namely implementing environmentally friendly policies, using curricula about the environment, participatory activities, and managing environmentally friendly supporting infrastructure. In implementing the Adiwiyata program, it can affect the character of caring for the environment for students. Character of caring for the environment is the knowledge and attitude of students in an effort to prevent damage and develop efforts to repair environmental damage. This article was created using the literature review method, which is to collect literature that is relevant both nationally and internationally. Several articles analyzed, the obstacles in the implementation of the Adiwiyata program, namely the unfulfilled allocation of funds, human resources, and infrastructure. One of the human resource factors is that students do not understand the concept of environmentally friendly schools. Therefore, the application of the character of caring for the environment is very important for development of knowledge and caring attitudes of students towards the environment.
\end{abstract}

Keywords: Adiwiyata, Implementation, Care characters

\section{INTRODUCTION}

Environmental education aims to provide school students with knowledge and understanding of the environment. Through environmental education, it can increase caring attitude towards the environment and reduce environmental damage in the future. In 2006, Ministry of National Education and the State Ministry of Environment collaborated to develop primary and secondary education programs through the Adiwiyata program. Based on the Regulation of the Minister of the Environment No. 05/2013 on Guidelines for the Implementation of the Adiwiyata Program, it is clear that the Adiwiyata is a program implemented to create a school that cares, has an insight, and has an environmental culture. According to the Adiwiyata Guidebook 2012, the program objectives to be achieved are described in four main components, namely: implementing environmentally friendly policies, using curricula about the environment, participatory activities, and managing environmentally friendly supporting infrastructure. Implementation of the Adiwiyata program has two basic principles, namely Participatory and Sustainable. Participatory means that school members are involved in all activities carried out in the school including the planning, implementation and evaluation processes. Meanwhile, sustainable means all activities carried out in a planned and comprehensive manner. all school members carry out these activities according to their responsibilities and roles

Implementation of the Adiwiyata program requires support from all school members, especially students as agents of change to create a better environment. The existence of the Adiwiyata program does not fully guarantee an increase in environmental awareness among students. One form of care that must be developed in students is to instill a caring character for 
the environment. The character of caring for the environment is related to instilling values and actions as an effort to care for the environment and prevent environmental damage.

One of the factors that occurs is that students still do not understand the concept of an environmental friendly school, so that integrated learning will provide a more meaningful experience to students through planting concepts, skills and values by connecting other concepts and skills that they already understand. According to Priyambodo et all. in explains that the implementation of character education can be integrated through the subjects given by the teacher. The process of simple character interaction can be done in the process of writing, reading, and social learning.

\section{METHODS}

Writing of this article uses the literature comparison method which is done by browsing literature online, consisting of books and journals related to learning strategies, learning methods, effective learning models during the pandemic. The steps used start from identification, article collection, article selection according to the criteria, and should be in accredited journals. Identification is done by screening articles that must contain specific words, namely "Implementation of the Adiwiyata Program", "Character Caring for Environment", and "Planting Character Caring for Environment in the Adiwiyata Program. Then article collection is done by collecting articles as many as 40 journals that match the criteria. The final step is selecting articles that pass the previous stage by checking the quality of the articles to analyzing the article as a result and discussing the article. In this literature review, there are 24 articles that match entitled "Adiwiyata Program Implementation in Inculcating Environmental Care Characters".

\section{RESULTS AND DISCUSSION}

\subsection{Implementation of The Adiwiyata Program}

Program in schools has components and standards in environmental management in accordance with Ministry of Environment regulations. Policies that must be implemented in schools, namely vision, mission, and objectives of the school include protection and management of the environment, environmental materials are integrated into subjects, provide additional hours to be used for environmental activities, and allocate funds for protection and management activities living environment. One of the school's visions is marked by the realization of a school environment and school members who care and have an environmental culture supported by the mission of building the character of school members to preserve the environment. Through this program, it is hoped that the school community will be responsible for environmental maintenance and sustainable development. However, there were obstacles in implementing the Adiwiyata program, namely the allocation of funds, human resources, and facilities. For the inadequate allocation of funds and facilities, schools hold fundraisers from inside and outside the school. Meanwhile, the lack of human resources regarding knowledge and environmental care attitudes from school residents is an obstacle in implementing the Adiwiyata program. Therefore, it is necessary to have a solution in dealing with these obstacles.

According to solutions in facing obstacles to implementation of the Adiwiyata program: PLH Development, Inculcating Environmental Care and Culture Habit, Optimizing LH Learning Support Facilities, Participating Actively with Environmental Action Activities, Creating Environmental Ambassador Student Cadres, Maximum Waste Management and Composting, Establishing a Class Forum to Care for the School Environment, and Creating an Environmental Mission.

The research on the development of virtual laboratory media obtained were 12 research articles. The study was obtained from various sources, namely research results in journals and research reports. Analysis of articles was carried out based on the level of education, the type and design of the study, the content/learning material, and the research results.

\subsection{Character Caring for Environment}

School as an educational institution that can play a role in building character in an integrated manner through the programs it carries out. The character of caring for the environment is a manifestation of human knowledge in values and ethics towards the environment. This character is expected to be applied in schools to have a positive impact on learning. The development of character care for the environment is integrated into learning through the implementation of an environment-based curriculum, an active learning process, and providing knowledge about protecting the environment properly. Gerungan (2004) explained in that the stimulus has an impact on individuals to 
respond and build one's behavior. According to The North American Association for Environmental Education (2001) in, several indicators show that students have succeeded in developing a character that cares for the environment towards the environment, namely: 1) increased awareness of lifelong learning, 2) have the ability to solve problems effectively and efficiently, 3) have the spirit of wise leadership in society 4) the formation of individuals who care about fellow humans, living things and the environment around them.

The formation of an appropriate culture of caring for the school environment will shape the character of students who care about the environment, culture that developed is the culture of 5S (Smile, Greetings, Say Hello, Polite, Courteous) and culture of $7 \mathrm{~K}$ (cleanliness, beauty, comfort, order, shade, health and safety).

\subsubsection{Environmental}

Knowledge of environmental management is provided through material on environmental education which is integrated into the subject by teachers to students. Argues that not only in subjects, environmental education is also integrated into extracurricular activities and self-development. According to research from, teachers remind students of the importance of caring for the environment and being able to maintain sustainability and cleanliness. In addition, the teacher initiatives to develop students with a lot of effort to carry out activities outside the classroom. In this case, an increase in environmental care behavior and a decrease in environmental damage indicates that knowledge of environmental care is increasing

\subsubsection{Environmental Care Attitude Environmental}

Care is an effort to raise awareness so that they do not only know about pollution, garbage, reforestation, and protection of endangered species, but can raise awareness of the environment, especially for students, so as to create a sustainable environment. According to, environmental care is divided into 3 scales, namely the attitude of protecting the school environment, the attitude of preserving the school environment, and the attitude of using natural environmental preservation.

\subsubsection{Attitudes toward Environmental}

\section{Protection}

Students' attitudes towards environmental protection, namely planting trees that aim to reduce air pollution caused by motorized vehicles and prevent flooding, as well as knowledge and practice of making biopores which aim to infiltrate water and produce compost. In addition, environmental protection can maintain ecological processes that support human survival.

\subsubsection{Attitudes toward Environmental}

\section{Preservation}

Students' attitudes towards environmental preservation are having a view on differentiating types of inorganic and organic waste. Inorganic is a type of waste that can be recycled, for example handicrafts from plastic bottles. Meanwhile, organic is waste that can be made into fertilizer. Then students can also think that reducing the use of paper can reduce the number of felled trees, as well as the use of learning tools that if they are not used, please turn them off because to save electricity usage. Preservation of the diversity of plant and animal species and their ecosystems can maintain their balance of life and avoid extinction.

\subsubsection{Attitudes Towards Environmental Utilization}

Students 'attitudes toward environmental use are environmentally friendly forms of use, it can be seen from the students' activities in utilizing used paper and plastic waste into creative and useful things, such as flower pots, miniatures of used paper liters, and others.

\subsection{The Obstacles in Building Student Caring Character of Environment}

There are several obstacles in building character of caring students for the environment at school. Firstly, it takes a long time for the character building process. In Fadillah et all. research, character building is due to the behaviour that is carried out continuously and then becomes a habit. This is obstacle because the student's learning period is only 3 years, maybe for the formation of behaviour can be done but for character building is not that easy. The second is student rotation, meaning that the school is clear and repetitive. Students who already know how to preserve 
the environment and master the organizational structure are then replaced by new student.

Third, it is difficult to integrate environmental education into subjects. A heavy learning and teaching load, it is difficult for teacher to pay attention to students caring behaviour. Teachers and students make the character of caring for the environment not a priority and limit students in doing activities outside the classroom. Lastly, it is difficult to be consistent. The successful implementation of the Adiwiyata program cannot be separated from the role of all school members. So, if the role is not good, then implementation Adiwiyata program will also not run well. Therefore, it is necessary to have the cooperation of school members in an absolute and sustainable manner.

\section{CONCLUSION}

Adiwiyata Program is a program organized by schools to achieve schools that care and have an environmental culture. Contains four important policies in the Adiwiyata program, namely implementing environmentally friendly policies, using curricula about the environment, participatory activities, and managing environmentally friendly supporting infrastructure. In implementing the Adiwiyata program there are several obstacles, one of which is human resources. Which means a lack of knowledge and environmental care from school residents. Therefore, it is necessary to instill a character that cares about the environment, especially for students. Environmental care character development is carried out by integrating it into learning. through an active learning process, implementing an environment-based curriculum, and providing knowledge about protecting the environment properly. There are three scales in the attitude of caring for the environment, namely protecting, maintaining and utilizing the preservation of the natural environment.

\section{ACKNOWLEDGMENTS}

Thank you to all parties who have supported the implementation of this research.

\section{REFERENCES}

[1] A. Putri, Implementasi Program Adiwiyata dalam Rangka Menciptakan Sekolah Peduli dan Berbudaya Lingkungan, Jurnal Tunas Bangsa 6 (1) 2019 37-47.
[2] A.F.B. Adam, Analisis Implementasi Kebijakan Kurikulum Berbasis Lingkungan Hidup pada Program Adiwiyata Mandiri di SD Negeri Dinoyo 2 Malang, Jurnal Kebijakan dan Pengembangan Pendidikan 2(2) (2014) 166-173. DOI: https://doi.org/10.22219/ jkpp.v2i2.1915

[3] A.S. Fridantara, Implementasi Program Adiwiyata di SMA Negeri 2 Klaten, Journal Eprint UNY (2016) 1-7.

[4] D.N.K. Wardani, Analisis Implementasi Program Adiwiyata dalam Membangun Karakter Peduli Lingkungan: Studi Kasus di MIN 1 Ponorogo, Southeast Asian Journal of Islamic Education Management 1(1) (2020) 60-73.

[5] E. Purwati, U.B. Wibowo, The principal leadership of the implementation of adiwiyata program in elementary school in Yogyakarta city, in: International Conference on Meaningful Education, vol. 2019, KnE Social Sciences, 2019, pp. 342-349. DOI: https://doi.org/10.18502/kss.v3i17.4656

[6] E. Riyanti, I. Maryani, Implementasi Program Adiwiyata dalam Pembentukan Karakter Peduli Lingkungan di SD Muhammadiyah Bodon Kotagede, Jurnal Fundamental Pendidikan Dasar 2(3) (2019) 109-116. DOI: https://doi.org/10.12928/fundadikdas.v2i3.1256

[7] Juraid, B. Hamzah, A. Mahpudz, R.I. Khaidun, Implementation and Development of Adiwiyata Schools to Realize Character of Students Care for Environment, International Journal of Scientific \& Technology Research 8 (2019) 1226-1229.

[8] Lasno, A. Suriansyah, M. Saleh, School Principal's Role in The Implementation of School-Based Management for Adiwiyata Program, European Journal of Education Studies 5 (2019) 105-122.

[9] L.S. Sunarti, Isjoni, Zulkarnaini, Pengaruh Implementasi Program Adiwiyata terhadap Perilaku Warga Sekolah pada Sekolah Adiwiyata Mandiri di Kota Pekanbaru, Jurnal Dinamika Lingkungan Indonesia 4(2) (2017) 139.

[10] M. Desfandi, E. Maryani, D. Disman, Building Ecoliteracy through Adiwiyata Program (Study at Adiwiyata School in Banda Aceh), Indonesian Journal of Geography 49(1) (2017) 51-56. DOI: https://doi.org/10.22146/ijg.11230

[11] M.D. Fathurahman, Implementation of Adiwiyata Program in Supporting Establishment 
of Enviroment Cares Character in 4 Public High School Pandeglang, GEA Journal of Geography Education 17(1) (2017) 25-27.

[12] M.K. Yasin, Character Education for Enviromental Awareness through The Adiwiyata Program, Islamic Studies Journal for Social Transformation 3(2) (2019) 127-145.

[13] Nashari, Implementasi Program Sekolah Adiwiyata (Studi pada SMP Negeri 6 Bantan Kecamatan Batan Kabupaten Bengkalis), Jurnal Akademika 13(2) (2017) 180-184.

[14] R. Adawiyah, Implementation of Adiwiyata Program to Build Environmental Awareness, Journal of Wetlans Environmental Management, 7(2) (2019) $106 . \quad$ DOI: http://dx.doi.org/10.20527/jwem.v7i2.196

[15] R. Ardiyanto, E. Banowati, E Suharini, Implementasi Program Adiwiiyata terhadap Sikap Peduli Siswa pada Lingkungan di SMA Negeri 1 Bandar Kabupaten Batang, Journal Education Gheography 6(6) (2018) 110-7.

[16] R.B. Ramdhani, Implementasi Program Adiwiyata dalam Pengelolaan Lingkungan Sekolah di SMP Negeri 3 Sukabumi, International Journal Pedagogy of Social Studies 1(2) (2016) 1-10.

[17] R. Saputro, D. Liesnoor, Implementasi Program Adiwiyata dalam Pengelolaan Lingkungan Sekolah di SMA Negeri 1 Jekulo Kudus, Edu Geography 3(6) (2015) 43-53.

[18] S.J. Silaban, F. Yuliani, Implementasi Program Adiwiyata (Studi pada SMP Negeri 20 Pekanbaru), Junal Online Mahasiswa 4(2) (2017) $1-15$.

[19] S. Nuzulia, S. Sukamto, A. Purnomo, Implementasi Program Adiwiyata Mandiri dalam Menanamkan Karakter Peduli Lingkungan Siswa, Social Science Education Journal 6(2) (2019) 155-164.

[20] S.U. Caddafie, N.K.T. Martuti, E. Rudyatmi, The Impact of Adiwiyata Program on Environmental Caring Character, Journal of Biology Education, 6(3) (2017) 350-356.

[21] U. Fadillah, S. Ngabekti, Lisdiana, The Adiwiyata School's Role in The Development of Character Caring for The Enviromrnt (A Case Study at the Junior High School 6 Tuban),
Journal of Innovative Science Education 7(1) (2018) 53-61.

[22] U. Rodiana, U.H. Asmara, Wahyudi, Implementasi Program Adiwiyata di SMP Negeri 3 Pontianak, Jurnal Pendidian dan Pembelajaran Khatulistiwa 3(9) (2014) 137-142.

[23] W. Anggraini, P. Karyanto, Sarwanto, Prihantomo, School and teachers' role to empowerment of environmental literacy in prominent middle school based on adiwiyata program, in: Journal of Physics: Conference Series, Vol. 123, IOP Publishing, Bristol, 2019, pp. 1-8.

[24] Y. Beanal, R.P. Situmorang, S.P. Hastuti, Implementasi Karakter Peduli Lingkungan Siswa pada Mata Pelajaran IPA-Biologi dalam Program Adiwiyata di SMP Negeri 7 Salatiga, Jurnal Bioma 8(2) (2019) 428-444. 